\title{
Stem cells therapy for cardiovascular repair in ischemic heart disease: How to predict and secure optimal outcome?
}

\author{
Jens Kastrup
}

Received: 6 December 2010 / Accepted: 10 January 2011 / Published online: 8 February 2011

(C) European Association for Predictive, Preventive and Personalised Medicine 2011

\begin{abstract}
Coronary artery disease is a growing problem worldwide. Early treatment with stabilizing drugs and revascularization by percutaneous coronary intervention or by-pass surgery has reduced the mortality significantly, but it is still the most common cause of death and a major cause of hospital admissions in industrialized countries. Treatment with stem cells with the potential to regenerate the damaged myocardium is a relatively new approach. However, the results from clinical studies on stem cell therapy for cardiac regeneration in patients with acute or chronic ischemic heart disease have been inconsistent. Some of the discrepancy could be due differences in study designs or patient selection. The review will based on conducted clinical stem cell trials try to elucidate how to predict and personalize this new treatment approach.
\end{abstract}

Keywords Advanced technologies · Ischemic heart disease $\cdot$ New therapeutic approaches $\cdot$ Regenerative medicine $\cdot$ Stem cell therapy

\section{Introduction}

Despite advances in drug therapy and percutaneous interventions, ischemic heart disease remains a major cause of mortality and morbidity in industrialized countries. Morbidity in survivors of the acute coronary syndrome is related to myocardial remodeling and progressive heart

J. Kastrup $(\bowtie)$

Cardiac Stem Cell laboratory and Cardiac Catheterization

Laboratory 2014, The Hearth Centre, Rigshospitalet,

Copenhagen University Hospital and Faculty of Health Sciences,

Blegdamsvej 9,

DK-2100 Copenhagen, Denmark

e-mail: jens.kastrup@rh.regionh.dk failure. It has, therefore, been a challenge in clinical research to find new treatment modalities that aim to reduce and repair the myocardial damage and improve blood supply to the myocardium in the ischemic heart.

Regenerative medicine with vascular growth factor and stem cell therapy have within the last decennium had great interest and have been tested in clinical trials in patients with ischemic heart disease [1]. The aim is to induce growth of new blood vessels or replacement of damaged myocardial cells either directly by transdifferentiation of stem cells or by a paracrine effect of cytokines secreted from the stem cells.

Within cardiology most focus has been on bone marrow derived hematopoietic stem cells, which have the potential to differentiate into endothelial cells and create new blood vessels and hereby be involved in myocardial vasculogenesis. Recently, several clinical safety and efficacy studies with mononuclear cell solutions (MNC) and selected endothelial progenitor cells (EPC) from the bone marrow have been conducted in patients with acute myocardial infarction (MI), chronic ischemic heart disease (CIHD) or ischemic heart failure (IHF). However, the results have been conflicting. Some but not all studies suggested a beneficial effect on myocardial function and on symptoms in acute and chronic myocardial ischemia [2-5].

These conflicting results have changed focus towards the use of a more specific stem cell line. Some groups have focused on the multi-potent mesenchymal stromal cell (MSC) from the bone marrow or adipose derived stem cell (ADSC), which easily can be isolated from the bone marrow and abdominal adipose tissue, in vitro culture expanded, and stimulated to differentiate into different cell lines as endothelial, cardiac or other cell types [6-8].

The aim of this review is to discuss current issues on regenerative stem cell therapy in patients with ischemic 
heart disease with focus on conducted clinical trials. With focus on predictive and personalized patient treatment the patient selection, stem cell type, cell source, delivery methods, stem cell mechanisms will be considered.

\section{Which stem cells are available for clinical treatment}

Stem cells are self-replicating and have the capacity to differentiate into at least one highly terminally differentiated specialized cell type [9]. Stem cells can be classified into three categories with different potency, which specifies their differentiation potential: 1. embryonic stem cells (ESC), 2. adult stem cells, and 3. induced pluripotent stem cells (iPS cells). Embryonic stem cells are derived from the inner cell mass of the blastocyte stage of the developing embryo. Adult stem cells are present in every tissue of the human body and are able to differentiate into those tissues. Most stem cells in clinical studies, whether it has been MNCs or MSCs, have been harvested from the bone marrow. However, MNCs and MSCs can also be harvested from peripheral blood [10], umbilical cord blood [11] and from adipose tissue [12]. In fact MSCs may reside in virtually all post-natal organs and tissues [13]. Finally through transcriptional reprogramming, somatic cells such as fibroblasts can be converted into iPS cells that resemble embryonic stem cells [14].

\section{Bone marrow derived mononuclear cells}

Bone marrow is the most frequent source of cells used in clinical cardiac regeneration, because they are the most easily accessible source of autologous cells for use in reparative transplantation. MNCs can easily be harvested from bone marrow aspirate and selected sub-fractions, as EPCs, can be isolated using markers on the cell surface. The use of the MNCs have the advantage of minimizing extensive in vitro manipulations compared with isolation and expansion of selected populations of cells. The potential disadvantage of using MNCs, which is a mixture of different cell types, is that the percentage of stem cells that are therapeutically useful may potentially be small. However, it is still debatable whether the potential clinical effect is caused by the stem cells or the cytokines secreted from the MNCs, since only $2 \%$ of the injected cells are stem cells [5].

Bone marrow derived mesenchymal stromal cells

MSCs are an easily obtainable stem cell source, which can be expanded in culture systems and differentiated into several different cell types in vitro under proper stimulation. For regenerative medicine MSCs have mostly been isolated from the low-density MNC population in the bone marrow, based on their selective adherence to plastic surfaces and by this method separated from the hematopoietic cells, which do not adhere to plastic surfaces [15]. The MSC population is rare in the bone marrow, accounting for only about $0.01 \%$ of bone marrow mononuclear cells [6]. Hence, the MSCs require substantial culture expansion for weeks prior to most experimental applications [16-18] (Fig. 1). MSCs can differentiate into endothelial progenitor cells by stimulating with vascular endothelial growth factor (VEGF) $[18,19]$ and into cardiomyocytes by a cocktail of growth factors [20], chemicals [21] or by microenvironment in vivo [22].

Adipose tissue derived stem cells

Due to the small number of MSCs in the bone marrow, an additional source of cells with the aforementioned multilineage properties is desirable [23]. An interesting alternative cell source is the ADSCs from adipose tissue. These ADSCs appear to have similar multi-lineage potential as bone marrow MSCs [24-27]. ADSCs can be retrieved via liposuction, and processed by enzymatic digestion, centrifugal enrichment and filtration methods [28]. The final cell solution adipose derived cells (ADC) contains an abundant population of ADSCs, approximately 100-300 fold more MSC-like cells than that found in bone marrow. Therefore, the following cultivation period to expand the number of ADSC can be reduced. For cell based therapies, the large number of ADSCs that can be harvested within a single surgical procedure could be an advantageous approach that reduced lengthy and costly in vitro culturing steps [29].

Induced pluripotent stem cells

An interesting new alternative cell type is iPS cells. These are adult somatic cells reprogrammed into pluripotent stem cells, by introducing pluripotency-associated transcription factors. The iPS cells acquire properties similar to those of ESCs $[14,30]$. This technology could potentially eliminate two important problems associated with ESCs: immune rejection after transplantation and the ethical concerns regarding the use of human embryos. But there are also other problems to be addressed for the iPS cells. One of these is teratoma formation identical to what is seen with ESCs [30, 31]. Even a small number of undifferentiated cells can result in the formation of teratomas. One way to solve this problem may be to induce differentiation of the iPS cells into the required cell types before treatment, leaving the few undifferentiated cells behind [32].

Current iPS cell technology depends largely on delivery of the reprogramming factors by use of retroviral or lentiviral vectors, which may lead to activation of oncogenes [33]. To ensure a safe clinical application of iPS-derived cells, 


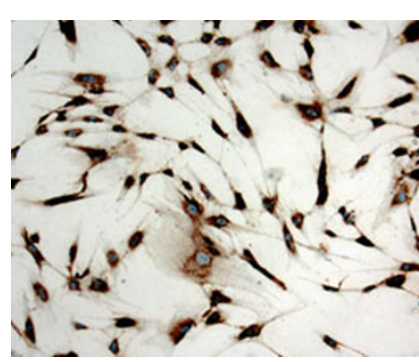

Week 1

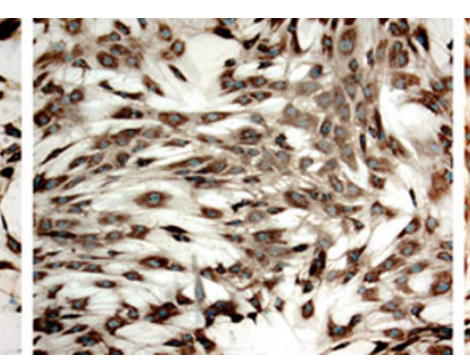

Week 2

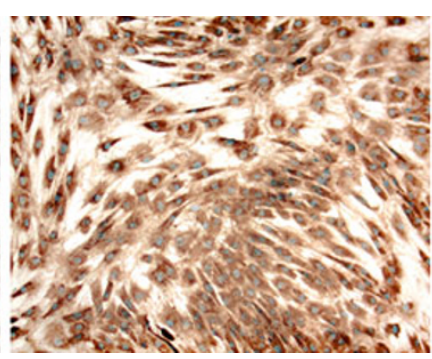

Week 3

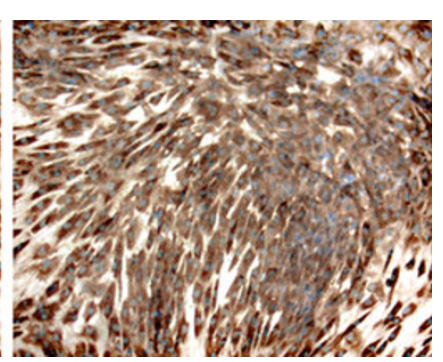

Week 5
Fig. 1 Cultivation of mesenchymal stromal cells for clinical treatment. Collagen staining. The cells needs several weeks of proliferation to reach a sufficient number for clinical treatment. The cells are becoming more and more confluent during cultivation and when they are approximately $80-90 \%$ confluent (week 5) they are harvested for treatment or for the next expansion passage developing non-viral methods for generating iPS cells, where inserted transgenes can be subsequently removed, is mandatory. The novel transposon-based and protein transduction methods allow for such a strategy [33, 34]. However, before iPS cells are ready for human clinical trials many open questions remain to be solved.

\section{Optimal stem cells delivery to the heart: advantages and disadvantages}

The optimal method for delivery of stem cell treatment to the damaged heart is still unclear. Most studies have used intravenous (IV), intracoronary (IC) or intramyocardial (IM) injection. For IC delivery most studies used a stopflow technique trough an over-the-wire balloon catheter positioned within the segment containing the stent. To allow for adhesion and potential transmigration of the infused cells through the endothelium, the balloon normally is inflated to completely block blood flow for 3 min while suspension of cells is infused distally to the occluding balloon [2-5].

Most studies using IM injection for delivery have used the NOGA XP system for mapping of the left ventricle and to guide the injections usually in the border area between normal and dead endocardial tissue or in the viable ischemic myocardium [35-37] (Fig. 2). Although IM injection of skeletal myoblasts have been demonstrated to have a pro-arrhythmogenic effect [37-39], IM injection of bone marrow derived stem cells and angiogenic genes have been reported to be safe without arrhythmias or death [5, 35-37, 41, 42].

A study on pigs with MI compared IV, IC and IM delivery of MSCs [43]. IC and IM delivery showed increased engraftment in the infracted heart compared to IV delivery, and IM injection of MSCs was found to be more efficient than IC delivery. A side effect of IC delivery was a decreased blood flow distal to the infusion site. The same side effect was seen in another study in dogs, where IC delivery of MSCs caused micro-infarction, probably due to microvascular obstruction caused by the rather large cell size of MSCs [44]. In opposition, a few clinical human studies have injected MSCs IC without complications [45-48].

\section{Stem cell regenerative potential: lessons from clinical trials with mononuclear cells}

Clinical stem cell therapy is still in its early experimental stages. Most clinical data have come from small nonrandomized and a few randomized, controlled trials conducted in patients with acute MI, CIHD and IHF with injection of stem cells either IC, IV, IM or during coronary artery by-pass grafting.

\section{Acute myocardial infarction}

Initial open-label trials of autologous MNCs documented safety and feasibility in patients with MI [49-52]. Then, larger independent randomized studies using autologous MNCs have been reported in MI patients [2-4, 53-61] (Table 1).

MNCs were in an open non-randomized study injected IC in 10 MI patients demonstrating increased LVEF, enhanced LV systolic function and reduced scar tissue after 3 months [50]. The same group recently reported 5-year data on an open non-randomized study on 62 IC treated patients with MI (the BALANCE study) [57]. Results supported the initial findings with improve LVEF and reduced scar tissue, in addition with an improved exercise capacity and reduced mortality in a 5-year follow-up period. The open randomized study on IC injection of MNCs in 30 STEMI patients (the BOOST trial) also showed increased LVEF and enhanced systolic function after 6 months [51], but after 18 months the difference in LVEF was no longer significant [58], suggesting that stem cell treatment merely accelerated LVEF recovery. The TOPCARE-AMI trial, another open randomized study on 
Fig. 2 NOGA mapping of left ventricle with intramyocardial injections of mesenchymal stromal cells (brown spots). A mapping catheter is introduced percutaneously from the groin into the left ventricle across the aortic valve. The catheter is then used for creating a tree-

dimensional image of the left ventricle and for injection of stem cells into the ventricular myocardium (outlined with the white line)

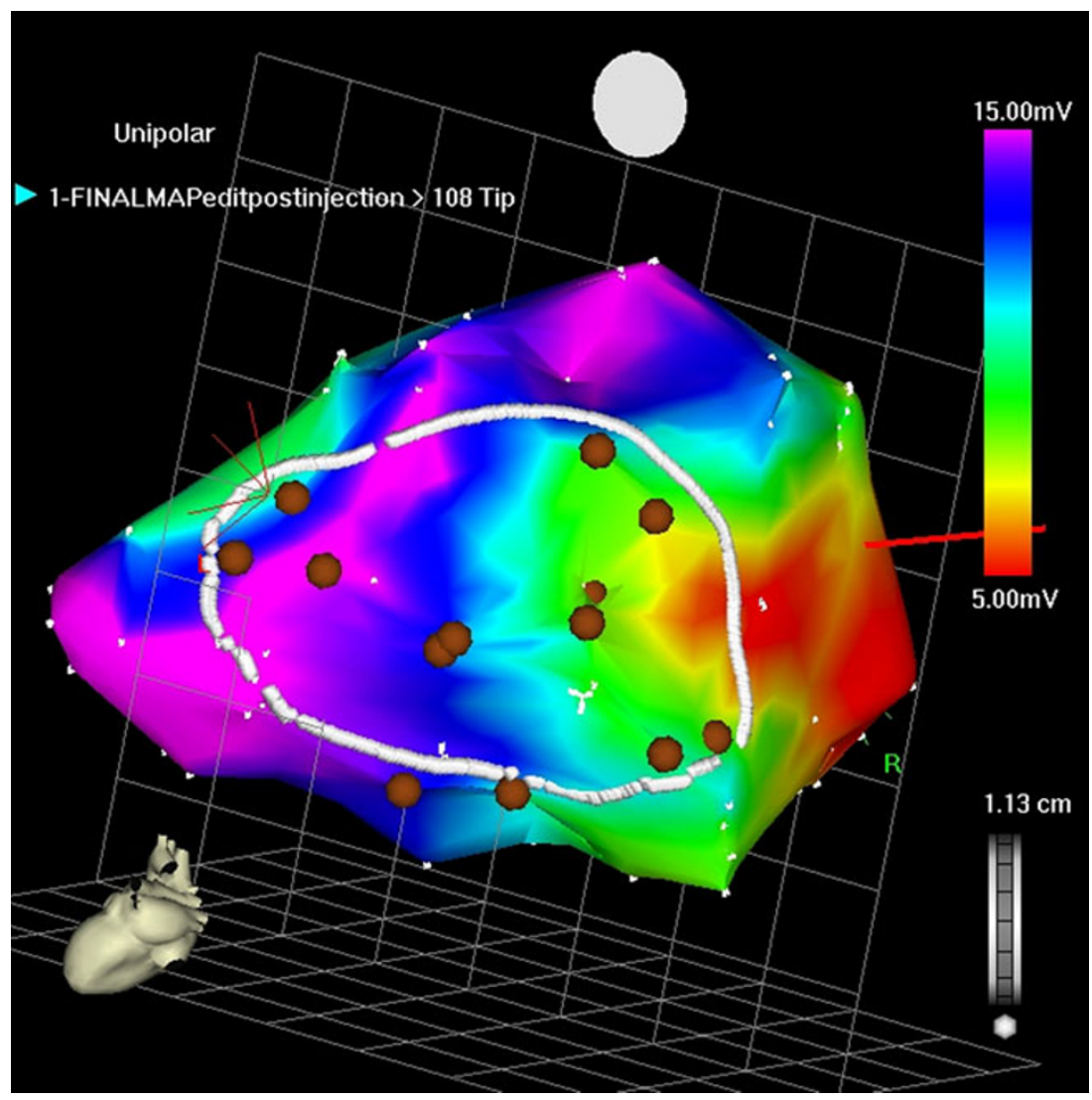

IC injection of either MNCs or circulating progenitor cells (CPC) in STEMI patients, showed improved LVEF and wall motion after 4 months (20 patients) [49] and also after 1 year (62 patients) [59]. There was no difference in effect between cell types. The REPAIR-AMI trial, a double blinded placebo controlled study on IC injected MNCs in 204 STEMI patients, showed improved LVEF and reduced mortality and re-hospitalization after 4 months [4] and the results were also stable after 1 year [60]. In opposition to these results, several trials have not been able to detect any

Table 1 Randomized controlled trials with bone marrow mononuclar cells in patients with acute myocardial infarction

\begin{tabular}{|c|c|c|c|c|c|c|c|}
\hline & $\begin{array}{l}\text { N Treated/ } \\
\text { controls }\end{array}$ & Cell type & Cell number & $\begin{array}{l}\text { Treatment } \\
\text { after MI }\end{array}$ & Administration & $\begin{array}{l}\text { Treatment } \\
\text { effect LVEF }\end{array}$ & $\begin{array}{l}\text { Infarct } \\
\text { size }\end{array}$ \\
\hline BOOST 2004 [51] & $30 / 30$ & $\mathrm{MNC}$ & $2500 \times 10^{6}$ & Day $6 \pm 1$ & i.c. & $\begin{array}{l}\uparrow(6 \text { months }) / \\
\leftrightarrow(18 \text { months })\end{array}$ & $\leftrightarrow$ \\
\hline $\begin{array}{l}\text { TOPCARE-AMI } \\
2002[49]\end{array}$ & $9 / 11$ & $\mathrm{MNC} / \mathrm{CPC}$ & $245 \times 10^{6} / 1010^{6}$ & Day 4 & i.c. & $\uparrow(4$ months $)$ & $\uparrow$ Viability \\
\hline REPAIR-AMI 2006 [60] & $101 / 103$ & $\mathrm{MNC}$ & $240 \times 10^{6}$ & Day 3-6 & i.c. & $\uparrow(4$ months $)$ & NA \\
\hline Leuven-AMI 2009 [2] & $33 / 34$ & $\mathrm{MNC}$ & $170 \times 10^{6}$ & Day 1 & i.c. & $\leftrightarrow(4$ months $)$ & $\downarrow$ \\
\hline ASTAMI 2006 [3] & $50 / 50$ & $\mathrm{MNC}$ & $87 \times 10^{6}$ & Day 6 & i.c. & $\leftrightarrow(6$ months $)$ & $\leftrightarrow$ \\
\hline FINCELL 2008 [54] & $40 / 40$ & $\mathrm{MNC}$ & $360 \times 10^{6}$ & Day 3 & i.c. & $\uparrow(6$ months $)$ & NA \\
\hline REGENT 2009 [56] & $80 / 80 / 40$ & 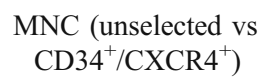 & $\begin{array}{l}180 \times 10^{6} \\
\text { vs } 1.9 \times 10^{6}\end{array}$ & Day 3-12 & i.c. & $\begin{array}{c}\leftrightarrow \text { between groups } \\
\text { (6 months) }\end{array}$ & NA \\
\hline HEBE 2008 [53] & $26 / 0$ & $\mathrm{MNC}$ & $246 \times 10^{6}$ & Day 3-8 & i.c. & $\uparrow(4$ months $)$ & $\downarrow$ \\
\hline BALANCE 2009 [57] & $62 / 62$ & $\mathrm{MNC}$ & $61 \times 10^{6}$ & Day 7 & i.c. & $\uparrow(43$ months $)$ & $\downarrow$ \\
\hline MYSTAR 2009 [55] & $60 / 0$ & $\begin{array}{r}\text { MNC (3-6 weeks) vs } \\
\text { MNC (3-6 months) }\end{array}$ & $\begin{array}{l}\text { i.m. } 200 \times 10^{6} \\
\text { vs } 200 \times 10^{6} \\
\text { i.c. } 1300 \times 10^{6} \\
\text { vs } 1300 \times 10^{6}\end{array}$ & $\begin{aligned} & \text { Day } 21-42 \\
& \text { vs } 90-120\end{aligned}$ & i.c. & $\uparrow(9-12$ months $)$ & \\
\hline
\end{tabular}

$M N C$ Bone marrow mononuclear cells, $C P C$ circulating progenitor cells, i.c. intracoronary, NA Not available 
effect of MNCs treatment on LV function after MI. The ASTAMI trial could not detect any improvement in LV function measured by magnetic resonance imaging (MRI) and SPECT in a randomized trial with IC injection of MNCs in 100 patients with MI [3]. Moreover, the Leuven MI trial with treated 67 patients with MI with either IC MNCs or placebo without any detectable effect on LV recovery measured by MRI [2]. However, the reduction in infarct size was greater in MNCs treated compared to placebo. In the HEBE trial, 200 patients with MI were treated with either MNC from bone marrow; MNC isolated form peripheral blood or treated with standard therapy [53]. The study could not demonstrate any improvements in global or regional LV systolic function assessed with MRI.

These conflicting clinical results have changed the focus towards the use of a more specific stem cell line or progenitor cell from the bone marrow to improve the outcome of the treatment. In the REGENT trial, Tendera et al. addressed this important issue by comparing IC infusion of unselected mononuclear cells with infusion of cells positive for surface markers CD34 and CXCR4 in patients with MI [56]. The REGENT trial was a multicenter study randomizing two hundred patients into IC infusion of bone marrow-derived mononuclear cells $(n=80), \mathrm{CD} 34+$ CXCR4+ cells $(n=80)$, or to a control group without cell treatment $(n=40)$. The study demonstrated no significant attenuation of left ventricular remodeling after cell therapy with absolute change in LVEF measured with MRI. However, this result should be interpreted with caution. The authors did observe an absolute increase of $3 \%$ in the patients treated with either of the two cell solutions compared to no change in the control group. This difference did not reach statistical significance but is comparable to the effect of cell therapy found in the larger randomized and blinded REPAIR-AMI trial $(2.5 \%, p=$ 0.01 ) and in the meta-analysis $[60,61]$. It could thus be argued that the REGENT trial is bias by a statistical type 1 error and also affected by a selection bias due to the nonblinded design. Gyöngyösi et al. tested the effect of repeated injections of MNCs. Patients with left ventricular ejection fraction less than $45 \%$ after $\mathrm{MI}$ were randomly assigned stem cell delivery via IM and IC infusion 36 weeks or 3-4 months after MI [54]. This combined MNC delivery treatment induced a moderate but significant improvement in myocardial infarct size and left ventricular function.

A meta-analysis from 2008 including 13 randomized controlled trials of bone marrow stem cell transplantation following MI reported a 2.99\% improvement in LVEF compared to controls $(p=0.0007)$ [61]. Whether these results still stands after inclusion of recent negative trials has to be clarified in new updated meta-analysis.
Ischemic heart failure

Intramyocardial injection of skeletal myoblasts during bypass surgery has been tested in 94 patients with ischemic heart failure (IHF) in the randomized placebo-controlled MAGIC trial [62] (Table 2). At the 6 months follow-up, there was no difference in regional or global LV function between the two groups. There was a trend towards more arrhythmias in the myoblast treated patients, confirming the safety concern that had been raised in earlier, nonrandomized trials. Perin et al. was the first group to inject MNCs directly IM using the percutaneous transendocardial method in 14 patients with IHF [5]. The method was safe and there was an improvement in LVEF and myocardial perfusion for up to 12 months compared to a control group $(n=7)$. Improved LVEF and NYHA class was also demonstrated in 15 patients with IHF after IM injection of MNCs [63]. The TOPCARE-CHD trial randomized 75 patients to either IC delivered MNCs or circulating progenitor cells (CPC) [64]. There was an improvement in LVEF, assessed with contrast angiography, with the MNC but not with the CPC treatment. Diederichsen et al. injected MNCs IC twice within a 4 months period in 32 patients with IHF without any effect on LVEF, but with an improvement in NYHA class [65]. In a recent trial Strauer et al. injected MNCs IC in 191 patients with IHF and follow the treated and a non-randomized control group for up to 5 years [66]. The study demonstrated improvement in LVEF, exercise capacity, oxygen uptake and long-term mortality in the entire follow-up period.

The more selected MNC subpopulation $\mathrm{CD}_{133^{+}}$has also been used in clinical trials. Ahmadi $\mathrm{H}$ et al., injected $\mathrm{CD}_{133^{+}} \mathrm{MNCs}$ directly into the infracted myocardium in 18 patients undergoing $\mathrm{CABG}$ and compared with patients which went through CABG alone [67]. They demonstrated a significant improvement of regional wall motion of akinetic/dyskinetic segments and perfusion of infracted areas in patients receiving local transplantation of $\mathrm{CD}_{133^{+}}$ cells in conjunction with $\mathrm{CABG}$ surgery, compared with a control group treated with CABD alone.

\section{Chronic ischemic heart disease}

Several small non-randomized and un-controlled trials with autologous MNCs have been conducted in patients with chronic ischemic heart disease (CIHD) [68-78] (Table 3). There was an improvement in LVEF, exercise capacity and symptoms in 20 patients with ICHD after IM injection of MNCs [69]. The same group demonstrated a few years later in 24 patients with CIHD that MNCs improved diastolic function 3 months after treatment [75]. Kang et al. demonstrated improved LVEF after IC injection of MNCs in opened total coronary occlusion [70]. Intramyocardial 
Table 2 Clinical trials with stem cells in patients with chronic ischemic heart failure

\begin{tabular}{|c|c|c|c|c|c|c|}
\hline & $\begin{array}{l}\mathrm{N} \text { treated/ } \\
\text { controls }\end{array}$ & Cell type & Cell number & Administration & $\begin{array}{l}\text { Treatment } \\
\text { effect LVEF }\end{array}$ & Symptoms \\
\hline Perin et al. 2004 [5] & $11 / 9$ & $\mathrm{MNC}$ & NA & i.c. & $\leftrightarrow(12$ months $)$ & NYHA $\downarrow$, exercise $\uparrow$ \\
\hline $\begin{array}{l}\text { Assmus et al. } \\
2006[64]\end{array}$ & $28 / 24 / 23$ & $\mathrm{MNC}$ vs CPC & $205 \times 10^{6} / 22 \times 10^{6}$ & i.c. & $\begin{array}{l}\mathrm{MNC} \uparrow / \mathrm{CPC} \leftrightarrow \\
(3 \text { months })\end{array}$ & NYHA MNC $\downarrow / C P C \leftrightarrow$ \\
\hline $\begin{array}{l}\text { Beeres et al. } \\
2007 \text { [63] }\end{array}$ & $15 / 0$ & $\mathrm{MNC}$ & $94 \times 10^{6}$ & i.c. & $\uparrow(3$ months $)$ & Exercise $\uparrow$ \\
\hline $\begin{array}{l}\text { Ahmadi et al. } \\
2007 \text { [67] }\end{array}$ & $18 / 9$ & $\mathrm{MNC}$ & & i.m. + CABG & NA & $\begin{array}{l}\text { Perfusion } \uparrow, \\
\text { wall motion } \uparrow\end{array}$ \\
\hline $\begin{array}{l}\text { Diederichsen et al. } \\
2008 \text { [65] }\end{array}$ & $32 / 0$ & $\begin{array}{l}\text { MNC (baseline) vs } \\
\text { MNC (4 months) }\end{array}$ & $650 \times 10^{6} / 890 \times 10^{6}$ & i.c. & $\leftrightarrow(12$ months $)$ & NYHA $\downarrow$ \\
\hline $\begin{array}{l}\text { Menarsche et al. } \\
2008 \text { [62] }\end{array}$ & $33 / 34 / 30$ & SKM & $400 \times 10^{6} / 800 \times 10^{6}$ & i.m. & $\leftrightarrow(6$ months $)$ & NA \\
\hline $\begin{array}{l}\text { Strauer et al. } \\
2010[66]\end{array}$ & $191 / 200$ & $\mathrm{MNC}$ & $66 \times 10^{6}$ & i.c. & $\uparrow(60$ months $)$ & Exercise $\uparrow$, mortality $\downarrow$ \\
\hline
\end{tabular}

$M N C$ Bone marrow mononuclear cells, SKM skeletal myoblasts, i.c. intracoronary, i.m. intramyocardial, $L V E F$ left ventricular ejection fraction, NYHA New York Heart Association class, NA not available

injection of MNCs has been used in 27 patients with advanced CIHD and followed for a year [40]. The study showed improvement of symptoms (Canadian Cardiovascular Society angina class (CCS)), exercise capacity and stress induced ischemic score. These data was supported by in the PROTECT-CAD trial, where IC injection of MNCs in 28 patients with CIHD improved NYHA class, exercise time and LVEF [76]. In a randomized, double-blind, placebo-controlled trial van Ramshorst et al. treated 50 patients with IM injections of MNCs or saline [77]. The study demonstrated improved myocardial perfusion, LVEF, exercise capacity and CCS class.

Losordo et al. injected IM increasing number of MNC subpopulation $\mathrm{CD}^{+} 4^{+}$cells in patients with CIHD [78]. The patients improved in angina, exercise capacity and antiangina medication. The disadvantage of the use of the MNC subpopulations $\mathrm{CD}_{133^{+}}$and $\mathrm{CD} 34^{+}$for clinical use is that they are usually only available in small and potential inadequate quantities from a patient, because the cells are very rare in bone marrow.

\section{The mesenchymal stromal cell: a more homogenous cell line for regeneration?}

Only a few small phase I/II safety and efficacy clinical studies on the therapeutic potency of human in vitro culture-expanded autologous MSCs in a less than 150

Table 3 Clinical trials with bone marrow mononuclear cells in patients with chronic ischemic heart disease

\begin{tabular}{|c|c|c|c|c|c|c|}
\hline & $\begin{array}{l}\mathrm{N} \text { treated/ } \\
\text { controls }\end{array}$ & Cell type & Cell number & Administration & $\begin{array}{l}\text { Treatment } \\
\text { effect LVEF }\end{array}$ & Symptoms \\
\hline Erbs et al. 2005 [68] & $13 / 13$ & $\mathrm{CPC}$ & $69 \times 10^{6}$ & i.c. & $\uparrow(3$ months $)$ & NA \\
\hline Fuchs et al. 2006 [41] & $27 / 0$ & $\mathrm{MNC}$ & $28 \times 10^{6}$ & i.c. & $\leftrightarrow(3$ and 12 months $)$ & $\mathrm{CCS} \downarrow$, exercise $\uparrow$ \\
\hline Beeres et al. 2006 [69] & $20 / 0$ & MNC & $30-100 \times 10^{6}$ & i.c. & $\uparrow(6$ months $)$ & $\operatorname{CCS} \downarrow$, exercise $\uparrow$ \\
\hline Hendrikx 2006 [71] & $10 / 10$ & $\mathrm{CABG}+/-\mathrm{MNC}$ & $60 \times 10^{6}$ & i.m. & $\leftrightarrow(4$ months $)$ & NA \\
\hline Kang et al. 2006 [70] & $25 / 25$ vs $16 / 16$ & $\mathrm{MNC}$ & $1400 \times 10^{6}$ & i.c. & $\begin{array}{l}\mathrm{MI} \uparrow / \mathrm{CIHD} \leftrightarrow \\
\quad(6 \text { months })\end{array}$ & NA \\
\hline Tse et al. 2007 [73] & $9 / 10 / 9$ & $\mathrm{MNC}$ & $17 \times 10^{6}, 42 \times 10^{6}$ & i.m. & $\uparrow(6$ months $)$ & NYHA $\downarrow$, exercise $\uparrow$ \\
\hline Losordo et al. 2007 [78] & $6 / 6 / 6 / 6$ & $\mathrm{CD} 34^{+}$ & $\begin{array}{l}0.05 \times 10^{6}, 0.1 \times 10^{6} \\
\text { or } 0.5 \times 10^{6}\end{array}$ & i.m. & NA(6 months $)$ & $\begin{array}{l}\text { CCS } \downarrow \text {, exercise } \uparrow, \\
\text { NTG } \downarrow\end{array}$ \\
\hline Beeres et al. 2008 [75] & $24 / 0$ & $\mathrm{MNC}$ & $85 \times 10^{6}$ & i.c. & $\leftrightarrow(3$ months $)$ & Diastolic function $\uparrow$ \\
\hline $\begin{array}{l}\text { Van Ramshorst et al. } \\
2009 \text { [77] }\end{array}$ & $25 / 25$ & $\mathrm{MNC}$ & $98 \times 10^{6}$ & i.m. & $\uparrow(3$ months $)$ & $\mathrm{CCS} \downarrow$, perfusion $\uparrow$ \\
\hline
\end{tabular}

$M N C$ Bone marrow mononuclear cells, $C P C$ circulating progenitor cells, i.c. intracoronary, i.m. intramyocardial, $L V E F$ left ventricular ejection fraction, CCS Canadian Cardiovascular Society angina class, NYHA New York Heart Association class; NTG Nitroglycerin consumption, NA not available 
patients with CIHD, MI or IHF have been published [4548, 79] (Table 4).

In an open study with IC administered MSCs in $11 \mathrm{MI}$ patients, the treatment was safe and showed improved wall motion index and non-viable segments [45]. The same group also investigated if there were any arrhythmogenic side-effects of MSCs treatment on five patients with an ICD units. Within 16-36 months follow up period there was no episodes of either sustained or non-sustained ventricular tachy-arrhythmia [46]. An open randomized study on IC delivered MSCs in 34 MI patients was safe and showed improved LV function after 6 months [47]. In another randomized study patients with severe heart failure were treated with MSCs IC and followed for a year [48]. The results showed improved LVEF, exercise capacity and NYHA class.

Safety of IV treatment with allogeneic bone marrow derived MSCs in patients with acute MI treated initially with balloon angioplasty was recently investigated in a randomized double-blind placebo-controlled doseescalating study [80]. The study demonstrated that the treatment was safe with identical adverse event rates between MSCs and placebo treated patients. However, MSCs treated patients had reduced ventricular tachycardia episodes, global symptom score and LVEF.

Kastrup et al. (unpublished data) has investigation the feasibility, safety and efficacy of IM injections of autologous MSCs derived endothelial precursor cell in patients with stable CIHD and refractory angina. The study demonstrated that it was possible and safe to culture expand MSCs and stimulate the cells with VEGF-A $A_{165}$ towards endothelial precursor cells and then to inject the cells directly into the ischemic myocardium of the patients. In addition, there was a graduate improvement in the patient's symptoms, exercise capacity, CCS class, angina attacks, nitroglycerine consumption and LVEF from baseline to 3 and 6 months follow-up.

\section{Conclusions}

Most of the clinical stem cell trials have used a pragmatic design with transplantation of a heterogeneous population of bone marrow-derived mononuclear cells-giving little information regarding the effective cell type. Some minor studies have tried to evaluate the efficacy of more specific cell lines as $\mathrm{CD} 34^{+}, \mathrm{CD} 133^{+}$or MSCs. However, the studies differed in design, patient numbers, cell preparation methods, timing of cell transplantation after percutaneous coronary intervention, and imaging modalities to evaluate the end-points. Some but not all studies suggested a beneficial effect on myocardial function and on symptoms. The reasons for these divergent findings are still unclear.

Mononuclear cell—what have we learned?

The REPAIR-AMI [60] and the ASTAMI [3] trials with MNCs treatment of patients with MI demonstrated completely opposite clinical outcome. Therefore, a comparison of the isolated cell infusate used in two studies was conducted by the REPAIR-AMI group. These results revealed important differences in bone marrow cell functionality, depending on laboratory procedure used [81]. The authors discuss whether lack of beneficial effect on the global left ventricular function could be related to impaired cell quality or insufficient cell number. However, Egeland and Brinchmann from the ASTAMI group did not agree about the cell quality question in ASTAMI study [82]. Presently this topic is still for discussion.

Table 4 Clinical studies with mesenchymal stromal cell (MSC) treatment of patients with ischemic heart disease

\begin{tabular}{|c|c|c|c|c|c|c|c|}
\hline & Patients & $\begin{array}{l}\text { N Treated/ } \\
\text { controls }\end{array}$ & Study design & Cell type & Cell number & Administration & Treatment effect \\
\hline Chen et al. 2004 [47] & MI & $34 / 35$ & I & MSC autologous & $6 \times 10^{10}$ & i.c. & LVEF $\uparrow$ \\
\hline Chen et al. 2006 [48] & MI & $22 / 62$ & I & MSC autologous & $5 \times 10^{6}$ & i.c. & LVEF $\uparrow$ exercise $\uparrow$ \\
\hline Katritsis et al. 2005 [45] & MI & $11 / 11$ & II & MSC autologous & & i.c. & LV wall motion $\uparrow$ \\
\hline Katritsis et al. 2007 [46] & MI & $5 / 0$ & II & MSC autologous & & i.c. & No arythmia \\
\hline $\begin{array}{l}\text { Mohyeddin-Bonab } \\
\text { et al. } 2007 \text { [79] }\end{array}$ & & $8 / 8$ & II & MSC autologous & & i.m. & $\mathrm{LVEF} \uparrow$ \\
\hline Hare et al. 2009 [80] & MI & $39 / 21$ & III & MSC allogeneic & $\begin{array}{c}0.5 \times 10^{6}, 1.6 \times \\
10^{6}, 5 \times 10^{6}\end{array}$ & i.v. & $\begin{array}{l}\text { Arythmia } \downarrow \text { lung } \\
\text { function } \uparrow \mathrm{LVEF} \uparrow\end{array}$ \\
\hline $\begin{array}{l}\text { Kastrup et al. } 2010 \\
\text { (unpublished) }\end{array}$ & CIHD & $31 / 0$ & I & MSC autologous & $22 \times 10^{6}$ & i.m. & $\begin{array}{c}\text { Exercise } \uparrow \text { LVEF } \uparrow \text { CCS } \downarrow \\
\text { NTG } \downarrow \text { ( } 6 \text { months })\end{array}$ \\
\hline
\end{tabular}

$M I$ acute myocardial infarction, $C I H D$ chronic ischemic heart disease, $I$ open randomized study, $I I$ open non-randomized study, $I I I$ randomized double-blind placebo controlled study, i.c. intracoronary, i.m. intramyocardial, i.v. intravenous, $L V E F$ left ventricular ejection fraction, CCS Canadian Cardiovascular Society angina class, NTG Nitroglycerin consumption 
Different cell types have been used in the different trials. Therefore, it has been discussed whether different cell types may give different clinical outcome. This question was addressed in the REGENT trial that compared the efficacy of IC injection of MNCs and $\mathrm{CD} 34^{+} \mathrm{CXCR}^{+}$cells in patients with MI [56]. The improvements in LVEF were virtually identical comparing these two cell populations. This may give important novel cell mechanistic insight. The selected cells $\mathrm{CD}^{2} 4^{+} \mathrm{CXCR}^{+}$were eluded from 100-120 mL bone marrow whereas the unselected cells MNCs (also containing $\mathrm{CD} 34^{+} \mathrm{CXCR}^{+}$) were eluted from $50-70 \mathrm{~mL}$ of bone marrow. Thus if the elution processes were identically effective then patients in the "selected" group were infused with approximately 2 times the number of $\mathrm{CD} 34^{+} \mathrm{CXCR}^{+}$ cells compared to the amount contained in the MNCs infused in the "unselected" patient group. The interpretation of this result is difficult; a similar improvement with unselected and selected cells argue in favor for a role of the selected $\mathrm{CD} 34^{+} \mathrm{CXCR}^{+}$cells in the mechanism behind the effect. However, if this effect is not dose dependent it would argue for a more indirect paracrine effect, e.g. via enhanced capillary growth, prevention of host cell death or even stimulation of resident stem cells. It is however, remarkable that enhanced mobilization from the bone marrow into the peripheral circulation of the same cell populations using granulocyte colony stimulating factor do not seem to improve functional outcome following MI [83, 84]. In contrast, a recent meta-analysis has suggested a dose dependent effect when infusing unselected mononuclear cells [61]. The number of cells used in the many different trials is very varying from a few millions to more than thousand millions. Therefore, the discrepancy in outcome in the clinical studies could be due to differences in amount of cells used in the treatment.

Mesenchymal stromal cells-a new treatment option?

MSCs are a very interesting cell line due to its multidifferentiation capacity. However, they are scanty in the bone marrow and therefore needs a period of culture expansion to reach a cell number of clinical relevance. The results from clinical trials in both patients with acute and chronic ischemic heart disease are promising, but more trials are needed to evaluate the clinical potential of the cells. ADSCs from adipose tissue seem to have the same differentiation capacity as MSCs from bone marrow. ADSCs are more abundant in and can easily be isolated from adipose tissue. However, they need to be culture expanded from the initial isolated adipose derived cells (ADC) under the same conditions as for MSCs to reach a clinical interesting level. The regenerative capacity of ADC and ADSC is presently tested in clinical trials in patients with acute and chronic ischemic heart disease.
In the PRECISE trial freshly isolated adipose derived cells (ADC) from the abdominal adipose tissue has been injected IM in 27 patients with IHF (Avilés et al., unpublished data). The study showed a reduction in the extent of infarct size in the left ventricle and an improvement in maximum oxygen consumption $\left(\mathrm{MVO}_{2}\right)$ and patients' aerobic capacity measured as metabolic equivalents (METS). The same ADCs were in the APOLLO trial injected IC in 14 patients with MI (Avilés et al., unpublished data). There was a trend towards reduction in infarct size.

\section{Which patients to treat}

Both the REGENT trial [56] and the REPAIR-AMI trial [60] have indicated that improvement in LVEF following cell therapy is mainly restricted to patients with low baseline LVEF. Therefore, future trials are focusing on larger infarctions. The timing of the treatment in relation to the acute MI is varying much between the different studies. In patients with MI it is suggested to postpone the treatment approximately one week after the infarction. The period could potentially be delayed for two to three weeks, since the spontaneous increase in circulating growth factors and homing factors reach their maximum two to three weeks after the infarction [85].

In most trials patients were only followed for a short period of time (3-6 months) for both efficacy and safety. There have been indications from the BOOST trial that the observed short-term improvement is not sustained over a prolonged period of time in patients with MI [58]. However, Strauer et al. could demonstrate persistent improvement after IC MNC treatment in patients with heart failure in a 5-years follow-up period [66].

A normal heart contains 20 million cardiomyocytes per gram of tissue [86]. Kajstura et al. estimated that the rate of cardiomyocyte proliferation in the healthy human heart is approximately 14 cardiomyocytes per million throughout life. In patients with end-stage ischemic heart disease, the rate rises more 10 -fold to 140 cardiomyocytes per million [87], yet this degree of turnover appears to be insufficient to compensate for the massive loss of cardiomyocytes experienced in chronic heart failure. A patient who has an infarct that eventually leads to cardiac failure must have destroyed roughly $25 \%$ of the left ventricle. Thus, one would expect that one billion cardiomyocytes are needed to improve cardiac function, which is well above the number of cells that current regenerative strategies can establish. In clinical regenerative trials with stem cells, the reparative effects are most likely through other mechanisms than direct differentiation toward functional tissue, which include diminishing inflammation, reducing apoptosis, inducing angiogenesis, stimulating paracrine effects or decreasing fibrosis. 


\section{Perspectives}

Regenerative medicine with stem therapy to restore normal cardiac function in patients with ischemic heart disease is a new treatment modality, which is explored intensively these years. Clinical studies on stem cell therapy for cardiac regeneration in patients with acute and chronic ischemic heart disease have in some but not all studies shown significant improvements in ventricular pump function, ventricular remodeling, myocardial perfusion, exercise capacity and clinical symptoms, compared to conventionally treated control/placebo groups. The mechanisms behind the potential regenerative capacity of stem cells could be replacement of the myocardium or blood vessels by trans-differentiation or more likely an effect of the cytokines produced by the stem cells on resident cells within the heart. The different treatment regimes using bone marrow or adipose tissue derived stem cell solutions have all been safe. However, there are still many unanswered questions regarding optimal cell type and number, cell source and delivery methods. Some of these questions will be answered in the ongoing or planned larger doubleblinded placebo controlled clinical trials to elucidate whether stem cell therapy will be a new treatment modality in patients with ischemic heart disease. When these results are available, then it will be possible to move forward for a more individual and personalized stem cell treatment strategy in patients with ischemic heart disease.

\section{References}

1. Kastrup J. Gene therapy and angiogenesis in patients with coronary artery disease. Expert Rev Cardiovasc Ther. 2010 Aug;8(8):1127-38.

2. Janssens S, Dubois C, Bogaert J, et al. Autologous bone marrowderived stem-cell transfer in patients with ST-segment elevation myocardial infarction: double-blind, randomised controlled trial. Lancet. 2006;367:113-21.

3. Lunde K, Solheim S, Aakhus S, et al. Intracoronary injection of mononuclear bone marrow cells in acute myocardial infarction. $\mathrm{N}$ Engl J Med. 2006;355:1199-209.

4. Schachinger V, Erbs S, Elsasser A, et al. Intracoronary bone marrow-derived progenitor cells in acute myocardial infarction. $\mathrm{N}$ Engl J Med. 2006;355:1210-21.

5. Perin EC, Dohmann HF, Borojevic R, et al. Transendocardial, autologous bone marrow cell transplantation for severe, chronic ischemic heart failure. Circulation. 2003;107:2294-302.

6. Pittenger MF, Martin BJ. Mesenchymal stem cells and their potential as cardiac therapeutics. Circ Res. 2004;95:9-20.

7. Haack-Sørensen M, Friis T, Kastrup J. Mesenchymal stromal cell and mononuclear cell therapy in heart disease. Future Medicine Future Cardiology. 2008;4:481-94.

8. Mathiasen AB, Haack-Sørensen M, Kastrup J. Mesenchymal stromal cells for cardiovascular repair: current status and future challenges. Future Cardiol. 2009;5:605-17.

9. Watt FM, Hogan BL. Out of Eden: stem cells and their niches. Science. 2000;287:1427-30.
10. Kuznetsov SA, Mankani MH, Gronthos S, et al. Circulating skeletal stem cells. J Cell Biol. 2001;153:1133-40.

11. Rosada C, Justesen J, Melsvik D, et al. The human umbilical cord blood: a potential source for osteoblast progenitor cells. Calcif issue Int. 2003;72:135-42.

12. Lee RH, Kim B, Choi I, et al. Characterization and expression analysis of mesenchymal stem cells from human bone marrow and adipose tissue. Cell Physiol Biochem. 2004;6:311-24.

13. da Silva ML, Chagastelles PC, Nardi NB. Mesenchymal stem cells reside in virtually all post-natal organs and tissues. J Cell Sci. 2006;11:2204-13.

14. Takahashi K, Yamanaka S. Induction of pluripotent stem cells from mouse embryonic and adult fibroblast cultures by defined factors. Cell. 2006;126:63-676.

15. Martinez C, Hofmann TJ, Marino R, et al. Human bone marrow mesenchymal stromal cells express the neural ganglioside GD2: a novel surface marker for the identification of MSCs. Blood. 2007;109:4245-8.

16. Horwitz EM. Mesenchymal stromal cells moving forward. Cytotherapy. 2008;10:5-6.

17. Haack-Sorensen M, Friis T, Bindslev L, et al. Comparison of different culture conditions for human mesenchymal stromal cells for clinical stem cell therapy. Scand J Clin Lab Invest. 2007;12:1-17.

18. Haack-Sorensen M, Bindslev L, Mortensen S, et al. The influence of freezing and storage on characteristics and functions of human mesenchymal stem cells isolated for clinical use. Cytotherapy. 2007;9:328-37.

19. Friis T, Haack-Sørensen M, Hansen SK, et al. Comparison of mesenchymal stromal cells from young healthy donors and patients with severe chronic coronary artery disease. Scand J Clin Lab Invest. 2011. doi:10.3109/00365513.2010.550310.

20. Lough J, Barron M, Brogley M, et al. Combined BMP-2 and FGF-4, but neither factor alone, induces cardiogenesis in nonprecardiac embryonic mesoderm. Dev Biol. 1996;178:198-202.

21. Makino S, Fukuda K, Miyoshi S, et al. Cardiomyocytes can be generated from marrow stromal cells in vitro. J Clin Invest. 1999;103:697-705.

22. Wang JS, Shum-Tim D, Galipeau J, et al. Marrow stromal cells for cellular cardiomyoplasty: feasibility and potential clinical advantages. J Thorac Cardiovasc Surg. 2000;120:999-1005.

23. Murohara T. Autologous adipose tissue as a new source of progenitor cells for therapeutic angiogenesis. J Cardiol. 2009;53:155-63.

24. Puissant B, Barreau C, Bourin P, et al. Immunomodulatory effect of human adipose tissue-derived adult stem cells: comparison with bone marrow mesenchymal stem cells. Br J Haematol. 2005;129:118-29.

25. Bochev I, Elmadjian G, Kyurkchiev D, et al. Mesenchymal stem cells from human bone marrow or adipose tissue differently modulate mitogen-stimulated B-cell immunoglobulin production in vitro. Cell Biol Int. 2008;32(4):384-93.

26. Fraser JK, Schreiber R, Strem B, et al. Plasticity of human adipose stem cells toward endothelial cells and cardiomyocytes. Nat Clin Pract Cardiovasc Med. 2006;3:S33-7-S33-S37.

27. Heydarkhan-Hagvall S, Schenke-Layland K, Yang JQ, et al. Human adipose stem cells: a potential cell source for cardiovascular tissue engineering. Cells Tissues Organs. 2008;187:263-74.

28. Zuk PA, Zhu M, Mizuno H, et al. Multilineage cells from human adipose tissue: implications for cell-based therapies. Tissue Eng. 2001;7:211-28.

29. Lin K, Matsubara Y, Masuda Y, et al. Characterization of adipose tissue-derived cells isolated with the Celution system. Cytotherapy. 2008;10:417-26.

30. Gunaseeli I, Doss MX, Antzelevtich C, et al. Induced pluripotent stem cells as a model for accelerated patient- and disease-specific drug discovery. Curr Med Chem. 2010;17(8):759-66. 
31. Li JY, Christophersen NS, Hall V, et al. Critical issues of clinical human embryonic stem cell therapy for brain repair. Trends Neurosci. 2008;31:146-53.

32. Yamanaka S. A fresh look at iPS cells. Cell. 2009;137:13-7.

33. Izsvak Z, Chuah MK, Vandendriessche T, et al. Efficient stable gene transfer into human cells by the Sleeping Beauty transposon vectors. Methods. 2009;49:287-97.

34. Yusa K, Rad R, Takeda J, et al. Generation of transgene-free induced pluripotent mouse stem cells by the piggyBac transposon. Nat Meth. 2009;6:363-9.

35. Perin EC, Dohmann HF, Borojevic R, et al. Improved exercise capacity and ischemia 6 and 12 months after transendocardial injection of autologous bone marrow mononuclear cells for ischemic cardiomyopathy. Circulation. 2004;110:II213-8.

36. Kastrup J, Jorgensen E, Ruck A, et al. Direct intramyocardial plasmid vascular endothelial growth factor-A165 gene therapy in patients with stable severe angina pectoris A randomized doubleblind placebo-controlled study: the Euroinject one trial. J Am Coll Cardiol. 2005;45:982-8.

37. Ripa RS, Wang Y, Jorgensen E, et al. Intramyocardial injection of vascular endothelial growth factor-A165 plasmid followed by granulocyte-colony stimulating factor to induce angiogenesis in patients with severe chronic ischaemic heart disease. Eur Heart J. 2006;27:1785-92.

38. Fernandes S, Amirault JC, Lande G, et al. Autologous myoblast transplantation after myocardial infarction increases the inducibility of ventricular arrhythmias. Cardiovasc Res. 2006;69:348-58.

39. Smits PC, van Geuns RJ, Poldermans D, et al. Catheter-based intramyocardial injection of autologous skeletal myoblasts as a primary treatment of ischemic heart failure: clinical experience with six-month follow-up. J Am Coll Cardiol. 2003;42:2063-9.

40. Veltman CE, Soliman OI, Geleijnse ML, et al. Four-year followup of treatment with intramyocardial skeletal myoblasts injection in patients with ischaemic cardiomyopathy. Eur Heart J. 2008;29:1386-96.

41. Fuchs S, Kornowski R, Weisz G, et al. Safety and feasibility of transendocardial autologous bone marrow cell transplantation in patients with advanced heart disease. Am J Cardiol. 2006;97:823-9.

42. Baldazzi F, Jorgensen E, Ripa RS, et al. Release of biomarkers of myocardial damage after direct intramyocardial injection of genes and stem cells via the percutaneous transluminal route. Eur Heart J. 2008;29:1819-26.

43. Freyman T, Polin G, Osman H, et al. A quantitative, randomized study evaluating three methods of mesenchymal stem cell delivery following myocardial infarction. Eur Heart J. 2006;27:1114-22.

44. Vulliet PR, Greeley M, Halloran SM, et al. Intracoronary arterial injection of mesenchymal stromal cells and microinfarction in dogs. Lancet. 2004;363:783-4.

45. Katritsis DG, Sotiropoulou PA, Karvouni E, et al. Transcoronary transplantation of autologous mesenchymal stem cells and endothelial progenitors into infarcted human myocardium. Catheter Cardiovasc Interv. 2005;65:321-9.

46. Katritsis DG, Sotiropoulou P, Giazitzoglou E, et al. Electrophysiological effects of intracoronary transplantation of autologous mesenchymal and endothelial progenitor cells. Europace. 2007;9:167-71.

47. Chen SL, Fang WW, Ye F, et al. Effect on left ventricular function of intracoronary transplantation of autologous bone marrow mesenchymal stem cell in patients with acute myocardial infarction. Am J Cardiol. 2004;94:92-5.

48. Chen S, Liu Z, Tian N, et al. Intracoronary transplantation of autologous bone marrow mesenchymal stem cells for ischemic cardiomyopathy due to isolated chronic occluded left anterior descending artery. J Invasive Cardiol. 2006;8:552-6.

49. Assmus B, Schachinger V, Teupe C, et al. Transplantation of progenitor cells and regeneration enhancement in acute myocardial infarction (TOPCARE-AMI). Circulation. 2002;106:3009-17.
50. Strauer BE, Brehm M, Zeus T, et al. Repair of infarcted myocardium by autologous intracoronary mononuclear bone marrow cell transplantation in humans. Circulation. 2002;106:1913-8.

51. Wollert KC, Meyer GP, Lotz J, et al. Intracoronary autologous bone-marrow cell transfer after myocardial infarction: the BOOST randomised controlled clinical trial. Lancet. 2004;364:141-8.

52. Fernandez-Aviles F, San Roman JA, Garcia-Frade J, et al. Experimental and clinical regenerative capability of human bone marrow cells after myocardial infarction. Circ Res. 2004;95 (7):742-8.

53. Hirsch A, Nijveldt R, van der Vleuten PA, et al. Intracoronary infusion of autologous mononuclear bone marrow cells in patients with acute myocardial infarction treated with primary PCI: Pilot study of the multicenter HEBE trial. Catheter Cardiovasc Interv. 2008;71:273-81.

54. Huikuri HV, Kervinen K, Niemela M, et al. Effects of intracoronary injection of mononuclear bone marrow cells on left ventricular function, arrhythmia risk profile, and restenosis after thrombolytic therapy of acute myocardial infarction. Eur Heart J. 2008;29:2723-32.

55. Gyongyosi M, Lang I, Dettke M, et al. Combined delivery approach of bone marrow mononuclear stem cells early and late after myocardial infarction: the MYSTAR prospective, randomized study. Nat Clin Pract Cardiovasc Med. 2009 Jan;6:70-81.

56. Tendera M, Wojakowski W, Ruzyłło W, et al. Intracoronary infusion of bone marrow-derived selected CD34+CXCR4+ cells and non-selected mononuclear cells in patients with acute STEMI and reduced left ventricular ejection fraction: results of randomized, multicentre Myocardial Regeneration by Intracoronary Infusion of Selected Population of Stem Cells in Acute Myocardial Infarction (REGENT) Trial. Eur Heart J. 2009;30:1313-21.

57. Yousef M, Schannwell CM, Kostering M, et al. The BALANCE study: clinical benefit and long-term outcome after intracoronary autologous bone marrow cell transplantation in patients with acute myocardial infarction. J Am Coll Cardiol. 2009;53:2262-9.

58. Meyer GP, Wollert KC, Lotz J, et al. Intracoronary bone marrow cell transfer after myocardial infarction: eighteen months' followup data from the randomized, controlled BOOST (BOne marrOw transfer to enhance ST-elevation infarct regeneration) trial. Circulation. 2006;113:1287-94.

59. Schachinger V, Assmus B, Britten MB, et al. Transplantation of progenitor cells and regeneration enhancement in acute myocardial infarction: final one-year results of the TOPCARE-AMI Trial. J Am Coll Cardiol. 2004;19:1690-9.

60. Schachinger V, Erbs S, Elsasser A, et al. Improved clinical outcome after intracoronary administration of bone-marrow-derived progenitor cells in acute myocardial infarction: final 1-year results of the REPAIR-AMI trial. Eur Heart J. 2006;27(23):2775-83.

61. Martin-Rendon E, Brunskill SJ, Hyde CJ, et al. Autologous bone marrow stem cells to treat acute myocardial infarction: a systematic review. Eur Heart J. 2008;29:1807-18.

62. Menasche P, Alfieri O, Janssens S, et al. The myoblastAutologous grafting in ischemic cardiomyopathy (MAGIC) trial: first randomized placebo-controlled study of myoblast transplantation. Circulation. 2008;117(9):1189-200.

63. Beeres SLMA, Bax JJ, Dibbets-Schneider P, et al. Intramyocardial injection of autologous bone marrow mononuclear cells in patients with chronic myocardial infarction and severe left ventricular dysfunction. Am J Cardiol. 2007;100:1094-8.

64. Assmus B, Honold B, Schächinger V, et al. Transcoronary transplantation of progenitor cells after myocardial infarction. N Engl J Med. 2006;355:1222-32.

65. Diederichsen ACP, Møller JE, Thayssen P, et al. Effect of intracoronary injection of bene marrow cells in patients with ischaemic heart failure. The Danish Stem Cell study — Congestive Heart Failure trial (DanCell-CHF). Eur J Heart Fail. 2008;10:661-7. 
66. Strauer BE, Yousef M, Schannwell CM. The acute and long-term effects of intracoronary Stem cell Transplantation in 191 patients with chronic HeSRt failure: the STAR-heart study. Eur J Heart Fail. 2010;12:721-9.

67. Ahmadi H, Baharvand H, Ashtiani SK, et al. Safety analysis and improved cardiac function following local autologous transplantation of CD133(+) enriched bone marrow cells after myocardial infarction. Curr Neurovasc Res. 2007;4(3):153-60.

68. Erbs S, Linke A, Adams V, et al. Transplantation of blood-derived progenitor cells after recanalization of chronic coronary artery occlusion: first randomized and placebo-controlled study. Circ Res. 2005;97(8):756-62.

69. Kang HJ, Lee HY, Na SH, et al. Differential effect of intracoronary infusion of mobilized peripheral blood stem cells by granulocyte colony-stimulating factor on left ventricular function and remodeling in patients with acute myocardial infarction versus old myocardial infarction. The MAGIC Cell-3-DES randomized, controlled trial. Circulation. 2006;114:I-145-I-151.

70. Beeres SLMA, Bax JJ, Kaandorp TAM, et al. Usefulness of intramyocardial injection of autologous bone marrow-derived mononuclear cells in patients with severe angina pectoris and stressinduced myocardial ischemia. Am J Cardiol. 2006;97:1326-31.

71. Hendrikx M, Hensen K, Clijsters C, et al. Recovery of regional but not global contractile function by the direct intramyocardial autologous bone marrow transplantation: results from a randomized controlled clinical trial. Circulation. 2006;114(1Suppl):I101-7.

72. Kuethe F, Richartz BM, Kasper C, et al. Autologous intracoronary mononuclear bone marrow cell transplantation in chronic ischemic cardiomyopathy in humans. Int J Cardiol. 2005;100(3):485-91.

73. Mocini D, Staibano M, Mele L, et al. Autologous bone marrow mononuclear cell transplantation in patients undergoing coronary artery bypass grafting. Am Heart J. 2006;151(1):192-7.

74. Strauer BE, Brehm M, Zeus T, et al. Regeneration of human infarcted heart muscle by intracoronary autologous bone marrow cell transplantation in chronic coronary artery disease: the IACT Study. J Am Coll Cardiol. 2005;46(9):1651-8.

75. Beeres SLMA, Lamb HJ, Roes SD, et al. Effect of intramyocardial bone marrow cell injection on diastolic function in patients with chronic myocardial ischemia. J Magn Reson Imaging. 2008;27:992-7.

76. Tze HF, Thambar S, Kwong YL, et al. Prospective randomized trial of direct endomyocardial implantation of boen marrow cells for treatment of severe coronary artery diseases (PROTECT-CAD trial). Eur Heart J. 2007;28:2998-3005.

77. Van Ramshorst J, Bax JJ, Beeres SLMA, et al. Intramyocardial bone marrow cell injection for chronic myocardial ischemia: a randomized controlled trial. JAMA. 2009;301(19):1997-2004.

78. Losordo DW, Schatz RA White CJ, et al. Intramyocardial transplantation of autologous $\mathrm{CD} 34^{+}$stem cellls for intractable angina. A phase I/IIa double-blind, randomized controlled trial. Circulation. 2007;115:3165-72.

79. Mohyeddin-Bonab M, Mohamad-Hassani MR, Alimoghaddam K, et al. Autologous in vitro expanded mesenchymal stem cell therapy for human old myocardial infarction. Arch Iran Med. 2007;10(4):467-73.

80. Hare JM, Traverse JH, Henry TD, et al. A randomized, doubleblind, placebo-controlled, dose-escalation study of intravenous adult human mesenchymal stem cells (prochymal) after acute myocardial infarction. J Am Coll Cardiol. 2009;54(24):2277-86.

81. Seeger FH, Tonn T, Krzossok N, et al. Cell isolation procedures matter: a comparison of different isolation protocols of bone marrow mononuclear cells used for cell therapy in patients with acute myocardial infarction. Eur Heart J. 2007;28(6):766-72.

82. Egeland T, Brinchmann JE. Cell quality in the ASTAMI study. Eur Heart J. 2007;28(17):2172-4.

83. Ripa RS, Jørgensen E, Wang Y, et al. Stem cell mobilization induced by subcutaneous granulocyte-colony stimulating factor to improve cardiac regeneration after acute st-elevation myocardial infarction. result of the double-blind randomized placebo controlled STEMMI trial. Circulation. 2006;113:1983-92.

84. Zohlnhöfer D, Dibra A, Koppara T, et al. Stem cell mobilization by granulocyte colony-stimulating factor for myocardial recovery after acute myocardial infarction: a meta-analysis. J Am Coll Cardiol. 2008;51:1429-37.

85. Wang Y, Johnsen HE, Bindslev L, et al. Changes in circulating mesenchymal stem cells, stem cell homing factor, and vascular growth factors in patients with acute ST elevation myocardial infarction treated with primary percutaneous coronary intervention. Heart. 2006;92(6):768-74.

86. Laflamme MA, Murry CE. Regenerating the heart. Nat Biotechnol. $2005 ; 23(7): 845-56$.

87. Kajstura J, Leri A, Finato N, et al. Myocyte proliferation in endstage cardiac failure in humans. Proc Natl Acad Sci USA. 1998;95 (15):8801-5. 